\title{
Impact of COVID-19 Containment Measures on Air Pollution in California
}

\author{
Aaron R. Naeger*, Kelley Murphy \\ Earth System Science Center, University of Alabama in Huntsville, Huntsville, AL 35805, USA
}

\begin{abstract}
This study used space- and ground-based sensors in conjunction meteorological and traffic information to evaluate the impact of the COVID-19 containment measures on air pollution in California by comparing data from March-April 2020 to the similar period in 2019. Although significantly lower pollution levels were observed throughout the COVID-19 containment period in 2020 compared to 2019, our meteorological analysis found that periods of enhanced precipitation likely contributed to the cleaner environment over the Central Valley and southern California. Therefore, we focused our assessment on a 19-day period of drier conditions across the region. During this period, TROPOspheric Monitoring Instrument (TROPOMI) data revealed strong reductions in tropospheric $\mathrm{NO}_{2}$ of $40 \%$ in Los Angeles, 38\% in Fresno, and about $20 \%$ in Bakersfield and San Francisco when compared to 2019. The reductions were mostly within about $10 \%$ of the decrease in vehicle miles traveled (VMT), which indicates that the decrease in traffic-related NO $_{x}$ due to the COVID-19 lockdown was an important driver of the $\mathrm{NO}_{2}$ reduction. Ozone Monitoring Instrument (OMI) data showed similar $\mathrm{NO}_{2}$ reductions to TROPOMI over Los Angeles during the lockdown, but drastically different results over the other cities where little to no reductions were observed. The close agreement between ground-based and TROPOMI observations indicated that a more accurate assessment of the impacts from the COVID-19 lockdown can be accomplished using TROPOMI rather than OMI data, which is attributed to its improved resolution and sensitivity that can better characterize $\mathrm{NO}_{2}$ pollution associated with fine-scale emissions. Altogether, the space- and ground-based observations provide strong evidence that the containment measures led to $\mathrm{NO}_{2}$ reductions of around 35\% in Los Angeles and Fresno and 25\% in San Francisco and Bakersfield relative to 2019, along with decreases in $\mathrm{PM}_{2.5}$ and improved air quality at the surface.
\end{abstract}

Keywords: Air pollution; Emissions, Automotive; Regional air quality; Remote sensing; $\mathrm{PM}_{2.5}$.

\section{INTRODUCTION}

Countries around the world implemented containment measures to limit person-to-person contact and prevent further spread of COVID-19. Although the containment measures varied in scope and restrictions, one general outcome was a slowdown in human and economic activity that led to fewer vehicles on the roadways and reduced industrial operations (Lee et al., 2020). Nitrogen oxides $\left(\mathrm{NO}_{\mathrm{x}}=\mathrm{NO}+\mathrm{NO}_{2}\right)$ emitted into the atmosphere from these anthropogenic sources are a major driver of ambient $\mathrm{NO}_{2}$ concentrations over populated areas of the globe (Lamsal et al., 2011). These anthropogenic sources also emit particulate matter (PM) and volatile organic compounds (VOCs), with motor vehicles being an important contributor of $\mathrm{PM}_{2.5}$ (Particulate Matter less than $2.5 \mu \mathrm{m}$ in diameter) in urban areas (Yan et al., 2011; Klimont et al., 2017). However, assessing the impacts of

\footnotetext{
* Corresponding author.

Tel: 1-256-961-7931; Fax: 1-256-961-7751

E-mail address: aaron.naeger@nasa.gov
}

source emissions to PM and VOC concentrations is more complicated than $\mathrm{NO}_{2}$ due to the numerous sources and chemical reactions that can govern the ambient levels in the atmosphere (Karagulian et al., 2015). Complex chemical reactions involving $\mathrm{NO}_{2}$ and VOCs in the presence of sunlight also lead to the formation of ozone $\left(\mathrm{O}_{3}\right)$ in the troposphere. $\mathrm{NO}_{2}, \mathrm{PM}_{2.5}$, VOCs, and $\mathrm{O}_{3}$ are recognized as key air pollutants that are associated with negative health effects, including cardiovascular disease, diabetes, and lung cancer (Ho et al., 2007; Kim et al., 2015; Strak et al. 2017). Consequently, the slowdown in vehicle and industrial activities from the implementation of COVID-19 containment measures could lead to significant reductions in air pollutants, particularly $\mathrm{NO}_{2}$, and positive health outcomes associated with cleaner air.

This study assesses the impacts of the COVID-19 containment measures on air pollution in California, with a focus on the cities of Los Angeles, San Francisco, Bakersfield, and Fresno. Effective air regulatory policies implemented in California led to emission reductions in $\mathrm{NO}_{\mathrm{x}}, \mathrm{VOCs}$, and $\mathrm{PM}_{2.5}$ of more than $50 \%, 60 \%$, and $20 \%$, respectively, from 1994 to 2011 (Lurmann et al., 2015), with mobile sources including gasoline and diesel vehicles accounting for about $83 \%$ of $\mathrm{NO}_{\mathrm{x}}$ emissions in the state by 2012 (Cook et al., 
2013). Nevertheless, additional emission reductions are needed as urban areas of California continue to experience air quality exceedances on a regular basis (Parrish et al., 2011). In the California's Central Valley and other rural areas of the state, $\mathrm{NO}_{\mathrm{x}}$ emissions from agriculture also contribute to air quality issues (Almarez et al., 2018). Overall, we expect that the adoption of COVID-19 containment measures in California in early March 2020 led to improved air quality conditions primarily due to drastic decreases in vehicular activity. This study will address the following science questions:

1) What is the impact of the COVID-19 containment measures on $\mathrm{NO}_{2}$ and $\mathrm{PM}_{2.5}$ concentrations in large cities across California?

2) Are the $\mathrm{NO}_{2}$ reductions observed from space consistent with the traffic activity and ground-based measurements?

To answer these questions, we use high-resolution satellite measurements in conjunction with ground-based measurements and transportation data during the pre- and post-initiation periods of containment measures in California.

\section{METHODS}

The space-based air quality measurements from the National Aeronautics and Space Administration (NASA) Ozone Monitoring Instrument (OMI) onboard the Aura satellite and the TROPOspheric Monitoring Instrument (TROPOMI) onboard the European Space Agency's (ESA) Sentinel-5 Precursor (Sentinel-5P) satellite were used for assessing the spatial and temporal evolution of tropospheric $\mathrm{NO}_{2}$ throughout California during the pre- and post-initiation of COVID-19 containment measures in the state. The OMI instrument has been continually monitoring air quality across the globe with a spatial resolution of $13 \times 24 \mathrm{~km}^{2}$ at nadir since its launch in 2004 (Torres et al., 2007). An extensive validation of the standard operational Level-2 data product from OMI showed that tropospheric $\mathrm{NO}_{2}$ retrievals from OMI were generally within $\pm 20 \%$ of ground-based column measurements (Lamsal et al., 2014). We use the OMI Level-3 daily global gridded $\mathrm{NO}_{2}$ product $(\mathrm{OMNO} 2 \mathrm{~d})$ that provides good quality, cloud-screened (cloud fraction < 30\%) Level-2 pixel data averaged onto a $0.25^{\circ} \times 0.25^{\circ}$ global grid. The long-term OMI Level-3 dataset will enable a climatological assessment of tropospheric $\mathrm{NO}_{2}$ in California for supporting the analysis of the COVID-19 containment measures on air pollution in the state. For assessing more recent trends in $\mathrm{NO}_{2}$ at higher spatial resolution than OMI, we use the newgeneration TROPOMI, which was launched in 2017 with a spatial resolution of $7.2 \times 3.5 \mathrm{~km}^{2}$ at nadir that was further enhanced to $5.6 \times 3.5 \mathrm{~km}^{2}$ beginning 6 August 2019 (Veefkind et al., 2012). Early validation of TROPOMI Level-2 off-line (OFFL) data against ground-based column measurements showed that the tropospheric $\mathrm{NO}_{2}$ products meet the bias requirements of $50 \%$ set by the satellite mission (Lambert et al., 2019). A close agreement (approximately 3\%) was also found between tropospheric $\mathrm{NO}_{2}$ from the TROPOMI OFFL and standard OMI product. In this study, we generate Level-3 daily gridded TROPOMI tropospheric $\mathrm{NO}_{2}$ at $0.05 \times 0.05^{\circ}$ grid spacing from the Level-2 OFFL product. Level-2 $\mathrm{NO}_{2}$ pixel-level retrievals associated with quality assurance values $>0.75$ are used to filter cloud-covered scenes (cloud radiance fraction $>0.5$ ), partially snow/ice covered scenes, and problematic retrievals. The TROPOMI and OMI are both onboard polar-orbiting satellites that provide once daily mid-day scans across the globe.

For assessing the impacts of the COVID-19 containment measures on air pollution at the surface, air monitoring stations operated by the California Air Resources Board (CARB) provided high-quality, continuous measurements of pollutant concentrations. The continuous measurements are then aggregated to hourly and daily time scales, with daily data being utilized in this study. We utilize station locations that are within a $15 \mathrm{~km}$ radius from city center and provide both $\mathrm{NO}_{2}$ and $\mathrm{PM}_{2.5}$ measurements. The distance threshold is based on our use of high-resolution TROPOMI data, which permits a robust comparison to ground-based observations over the most densely populated areas of the cities. After applying the criteria, we use daily $\mathrm{NO}_{2}$ and $\mathrm{PM}_{2.5}$ data from one station each in Los Angeles, Fresno, and Bakersfield, and two stations around San Francisco, including a station at Laney College in Oakland directly across the San Francisco Bay.

To examine vehicle activity in response to the containment measures, we utilize data from the Caltrans Performance Measurement System (PeMS; http://pems.dot.ca.gov/) operated by the California Department of Transportation. PeMS collects real-time traffic data from over 40,000 vehicle detector stations that span the freeway systems across the major metropolitan areas of California (Chen et al., 2003). The detectors measure average traffic flow rate and freeway occupancy that are input into statistical models to calculate traffic quantities including vehicle-hours traveled (VHT) and vehicle-miles traveled (VMT). This study uses total VMT and truck VMT in the cities of Los Angeles, San Francisco, Fresno, and Bakersfield, in an effort to diagnose changes in traffic activity in conjunction with the pollutant data. McDonald et al. (2012) found that diesel engines contributed about $40 \%$ and $70 \%$ to on-road $\mathrm{NO}_{\mathrm{x}}$ emissions around Los Angeles and the San Joaquin Valley, respectively, in 2010, which highlights the importance of analyzing the trends in truck activity.

Lastly, meteorological data was assessed to examine the potential role of natural weather variability on the pollutant concentrations during the COVID-19 containment measures in California. Zhou et al. (2012) found a significant impact from wind on OMI tropospheric $\mathrm{NO}_{2}$ columns, with strong anticorrelations between wind speed and $\mathrm{NO}_{2}$ while wind direction determined how air from surrounding areas influenced local pollution. More specifically, transport from cleaner areas led to local $\mathrm{NO}_{2}$ reductions. This study also found a seasonal variation in precipitation impacts on $\mathrm{NO}_{2}$ depending on soil $\mathrm{NO}_{\mathrm{x}}$ emissions, with generally lower tropospheric $\mathrm{NO}_{2}$ by about $10-30 \%$ after precipitation during the cold season in Europe when emissions from agricultural areas were lower than in the warm season. Other studies have found similar relationships between these meteorological parameters and $\mathrm{NO}_{2}$ concentrations (Kim et al., 2014; Grundstrőm et al., 2015). Variability in $\mathrm{NO}_{2}$ can also be dependent on ambient temperatures as warmer temperatures promote shorter $\mathrm{NO}_{2}$ lifetimes and lower concentrations in the 
troposphere (Seinfeld and Pandis, 2006). For this reason, we conduct a regional assessment of the temperature and wind fields over California from the Rapid Refresh (RAP) analysis dataset at $13 \mathrm{~km}$ grid spacing (Benjamin et al., 2016), in addition to a precipitation analysis in the selected major cities using Parameter-Elevation Regressions on Independent Slopes Model (PRISM) data with $4 \mathrm{~km}$ resolution (Daly et al., 2008). Quality-control procedures are used during the production of both of these datasets to limit the impact of observational errors on the final product as discussed in Daly et al. (2008) and Benjamin et al. (2016).

\section{RESULTS AND DISCUSSION}

\section{Meteorological Setup}

We compare meteorological parameters throughout California during a 5-week period when COVID-19 containment measures were in order $\left(9^{\text {th }}\right.$ March- $10^{\text {th }}$ April
2020) to the analogous period in 2019 (11 ${ }^{\text {th }}$ March-12 $2^{\text {th }}$ April 2019). Vertically averaged wind speed and direction from the surface to $500 \mathrm{hPa}$ are assessed to consider the impact of boundary layer and free tropospheric winds on the space-based $\mathrm{NO}_{2}$ columns (e.g., Zhou et al., 2012). The most notable differences in wind direction occurred over southern California where winds shifted from northwesterly in 2019 (Fig. 1(a)) to westerly in 2020 (Fig. 1(b)). Westerly winds over Los Angeles could promote local reductions in $\mathrm{NO}_{2}$ due to the transport of cleaner air from the Pacific Ocean. Furthermore, wind speeds and $2 \mathrm{~m}$ temperatures were lower by about 5 knots and 2 to $4^{\circ} \mathrm{C}$ in 2020 than in 2019 across much of California with perhaps the most noticeable temperature differences around Los Angeles. This combination of lower wind speeds and temperatures across California suggest that the meteorological setup was more conducive to higher pollutant levels during the COVID-19 containment measures in 2020 compared to the previous year. On the other hand,
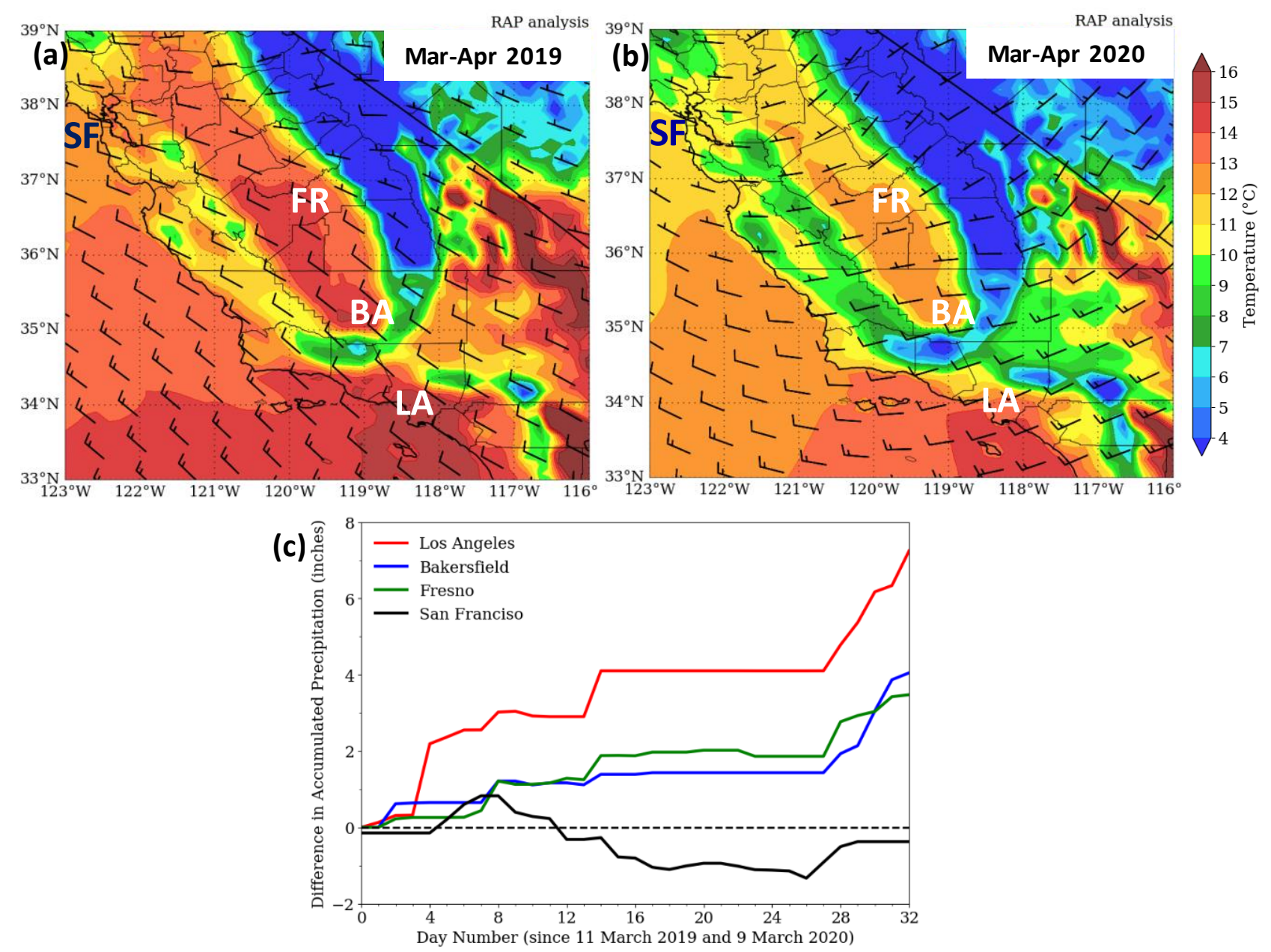

Fig. 1. (a) $2 \mathrm{~m}$ temperature and vertically averaged wind speed and direction from the surface to $500 \mathrm{hPa}$ for $11^{\text {th }} \mathrm{March}-$ $12^{\text {th }}$ April 2019 from RAP analysis data at $13 \mathrm{~km}$ grid spacing. (b) Same as (a), except for $9^{\text {th }}$ March-10 ${ }^{\text {th }}$ April 2020 during the COVID-19 containment measures. Maps were produced from averaging hourly RAP analysis data during the 5-week periods in 2019 and 2020. Labels FR and BR represent approximate locations of Fresno and Bakersfield, respectively. (c) Difference in accumulated precipitation from PRISM data over Los Angeles, Bakersfield, Fresno, and San Francisco between 2020 and 2019 for the same period used to produce the RAP analysis maps. The starting day number represents $11^{\text {th }}$ March in 2019 and $9^{\text {th }}$ March in 2020. 
much wetter conditions persisted across southern California and the Central Valley in 2020 compared to 2019 due to several baroclinic systems that brought large rainfall amounts to the region in early to mid-March and early April. We can expect the larger precipitation amounts to promote reductions in pollutants, since soil $\mathrm{NO}_{\mathrm{x}}$ emissions are generally low during this spring transition period in California (Hudman et al., 2010). An opposite scenario occurred in San Francisco as more rainfall fell in 2019 than in 2020 with maximum differences of about 1 inch by late March. Altogether, the meteorological conditions over San Francisco were less favorable for pollution in 2019 compared to 2020, while periods of enhanced precipitation across the Central Valley and southern California in 2020 likely contributed to the pollutant reductions in Los Angeles, Fresno, and Bakersfield.

\section{Phases of COVID-19 Measures and Traffic Changes}

PeMS traffic data reveals a distinct decreasing trend in VMT from the pre- to post-initiation periods of COVID-19 containment measures adopted in the state (Fig. 2). During the first weekday period of March $\left(2^{\text {nd }}-6^{\text {th }}\right.$ March $)$ when COVID-19 measures were yet to be implemented, total VMT showed normal trends in Los Angeles, Bakersfield, Fresno, and San Francisco. As cities in California began to restrict large group gatherings and announce school closures (Phase 1) during the second week of March $\left(9^{\text {th }}-13^{\text {th }}\right.$ March), an average reduction in VMT of up to $5 \%$ occurred throughout these cities compared to the pre-containment week. After California announced a statewide "shelter in place" order (Phase 2) the third weekday period of March $\left(16^{\text {th }}-20^{\text {th }}\right.$ March), more dramatic changes in VMT were observed including 10-25\% reductions in Bakersfield, Los Angeles, and Fresno, and greater than $30 \%$ reductions in San Francisco relative to the pre-containment week. Additional VMT reductions of 6 $12 \%$ occurred during the final weekday period of March $\left(23^{\text {rd }}\right.$ $27^{\text {th }}$ March), which represented the near lower limit of VMT as vehicle activity was mostly unchanged into April. Total average reductions in VMT during this time series range from $18 \%$ in Bakersfield to $40 \%$ in San Francisco when compared to the first weekday of March. The weekend effect of reduced traffic compared to the weekday is also apparent in the VMT time series, which appears to become stronger after the initiation of COVID-19 containment measures.

When comparing average VMT during the Phase 2 period of the COVID-19 measures in 2020 to the same period in 2019, similar trends are found in the large cities with $43 \%$, $32 \%$, and $19 \%$ reductions in San Francisco, Los Angeles, and Bakersfield, respectively. A more significant decrease in traffic activity occurred in Fresno where VMT was about 49\% higher in 2019 compared to 2020. Although trucks represent only a small fraction of the total on-road vehicles with the highest percentages of about $6 \%$ in Fresno and Bakersfield, they can still be significant contributors to $\mathrm{NO}_{\mathrm{x}}$ emissions (McDonald et al., 2012). PeMS traffic data also shows strong declines in truck activity after the implementation of Phase 2 measures with decreases of $25 \%$ in Los Angeles to $54 \%$ in Bakersfield when comparing the similar periods in 2019 and 2020. Table 1 summarizes the changes in VMT from 2019 to 2020.

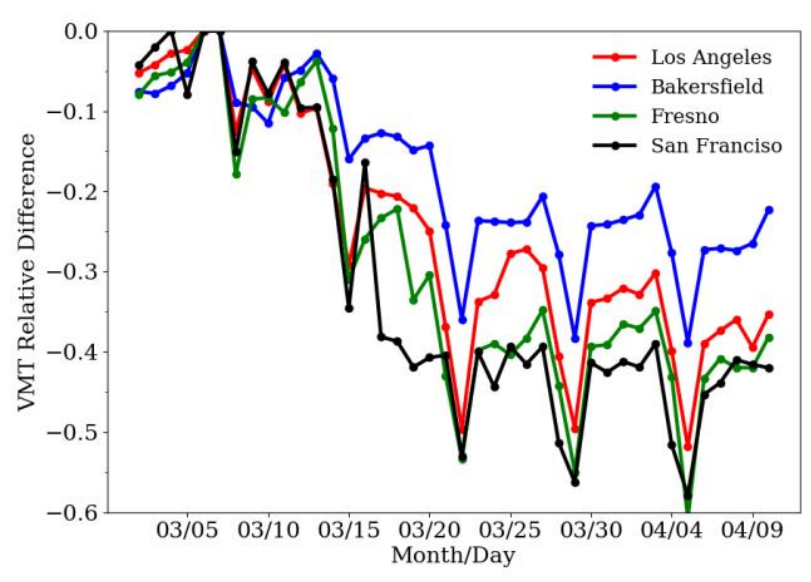

Fig. 2. Weekday and weekend relative differences in daily VMT along the freeways in Los Angeles, Bakersfield, Fresno, and San Francisco from $2^{\text {nd }}$ March-10 ${ }^{\text {th }}$ April 2020. Reference values for relative difference calculations are maximum weekday and weekend VMT during time series.

\section{Space-based $\mathrm{NO}_{2}$ Analysis}

Fig. 3 shows the weekday trends in TROPOMI tropospheric $\mathrm{NO}_{2}$ columns throughout California during the same period as shown in the VMT time series. Prior to the COVID-19 containment measures ( $2^{\text {nd }}-6^{\text {th }}$ March $)$, the largest tropospheric $\mathrm{NO}_{2}$ columns exceeding $12.0 \times 10^{15}$ molecules $\mathrm{cm}^{-2}$ were observed in Los Angeles and bordering counties with a less prominent peak near $6.3 \times 10^{15}$ molecules $\mathrm{cm}^{-2}$ around San Francisco (Fig. 3(a)). TROPOMI also measured areas of enhanced $\mathrm{NO}_{2}$ exceeding $5.0 \times 10^{15}$ molecules $\mathrm{cm}^{-2}$ along the heavily trafficked corridor of State Route 99 (SR-99) in the Central Valley, particularly around the cities of Bakersfield and Fresno. As Phase 1 measures were announced the next week $\left(9^{\text {th }}-13^{\text {th }}\right.$ March), TROPOMI observed $23-43 \%$ reductions in tropospheric $\mathrm{NO}_{2}$ columns over the large cities in California compared to the pre-containment week with the largest reductions in Los Angeles (Fig. 3(b)). The relatively small decreases in VMT of up to $5 \%$ in the cities cannot explain these $\mathrm{NO}_{2}$ reductions (i.e., Fig. 2), which strongly suggests that natural weather variability and higher mid-day solar angles during this seasonal transition period were the major contributing factors to the reduction. In particular, significant precipitation across much of the Central Valley and southern California during this week likely played a major role in the large $\mathrm{NO}_{2}$ reductions.

The Phase 2 statewide "shelter in place" order led to further decreases in tropospheric $\mathrm{NO}_{2}$ columns during the third weekday period of March $\left(16^{\text {th }}-20^{\text {th }}\right.$ March). This week was also much drier across most of the region, except for an area of enhanced precipitation in Fresno early in the week that likely contributed to the large $\mathrm{NO}_{2}$ reductions of more than $50 \%$ in this area compared to the previous week (Fig. 3(c)). The moderate decreases in $\mathrm{NO}_{2}$ levels in San Francisco and Bakersfield of about $20 \%$ were more consistent with the steep decreases in VMT of $20-30 \%$ from the previous week. Although VMT decreased about $15 \%$ in Los Angeles, tropospheric $\mathrm{NO}_{2}$ columns were relatively unchanged across the city, which is likely associated with cleaner air 
Table 1. Average of total VMT and tropospheric $\mathrm{NO}_{2}$ columns $\left(10^{15}\right.$ molecules $\left.\mathrm{cm}^{-2}\right)$ for period in 2020 during Phase 2 containment measures $\left(16^{\text {th }}\right.$ March-10 ${ }^{\text {th }}$ April) and analogous period in 2019 (18 ${ }^{\text {th }}$ March-12 $2^{\text {th }}$ April). Tropospheric $\mathrm{NO}_{2}$ columns from both TROPOMI and OMI are shown with bracketed numbers representing OMI. Relative differences in percent between 2020 and 2019 values are shown in bottom row. Differences are negative unless preceded by a positive sign. Numbers in parentheses represent differences in truck VMT between 2020 and 2019 periods. Specific coordinates of city centers are defined as $34.07^{\circ} \mathrm{N}$ and $118.23^{\circ} \mathrm{W}$ (Los Angeles), $37.79^{\circ} \mathrm{N}$ and $122.26^{\circ} \mathrm{W}$ (San Francisco), 36.79 ${ }^{\circ} \mathrm{N}$ and $119.77^{\circ} \mathrm{W}$ (Fresno), and $35.36^{\circ} \mathrm{N}$ and $119.06^{\circ} \mathrm{W}$ (Bakersfield).

\begin{tabular}{|c|c|c|c|c|c|c|c|c|}
\hline \multirow{2}{*}{ Year } & \multicolumn{2}{|c|}{ Los Angeles } & \multicolumn{2}{|c|}{ San Francisco } & \multicolumn{2}{|c|}{ Fresno } & \multicolumn{2}{|c|}{ Bakersfield } \\
\hline & $\operatorname{VMT}\left(10^{7}\right)$ & $\mathrm{NO}_{2}$ & VMT $\left(10^{6}\right)$ & $\mathrm{NO}_{2}$ & VMT $\left(10^{6}\right)$ & $\mathrm{NO}_{2}$ & VMT $\left(10^{5}\right)$ & $\mathrm{NO}_{2}$ \\
\hline 2019 & 3.9 & $14.8[7.5]$ & 3.5 & 3.6 [2.9] & 3.8 & $2.8[1.4]$ & 3.9 & $3.1[1.5]$ \\
\hline 2020 & 2.7 & $8.8[5.5]$ & 2.0 & $2.9[2.8]$ & 1.9 & $1.8[1.5]$ & 3.1 & 2.5 [1.9] \\
\hline 2020-2019 & $32(25)$ & $40[30]$ & $43(44)$ & $19[4]$ & 49 (39) & $38[+5]$ & $19(54)$ & $20[+24]$ \\
\hline
\end{tabular}
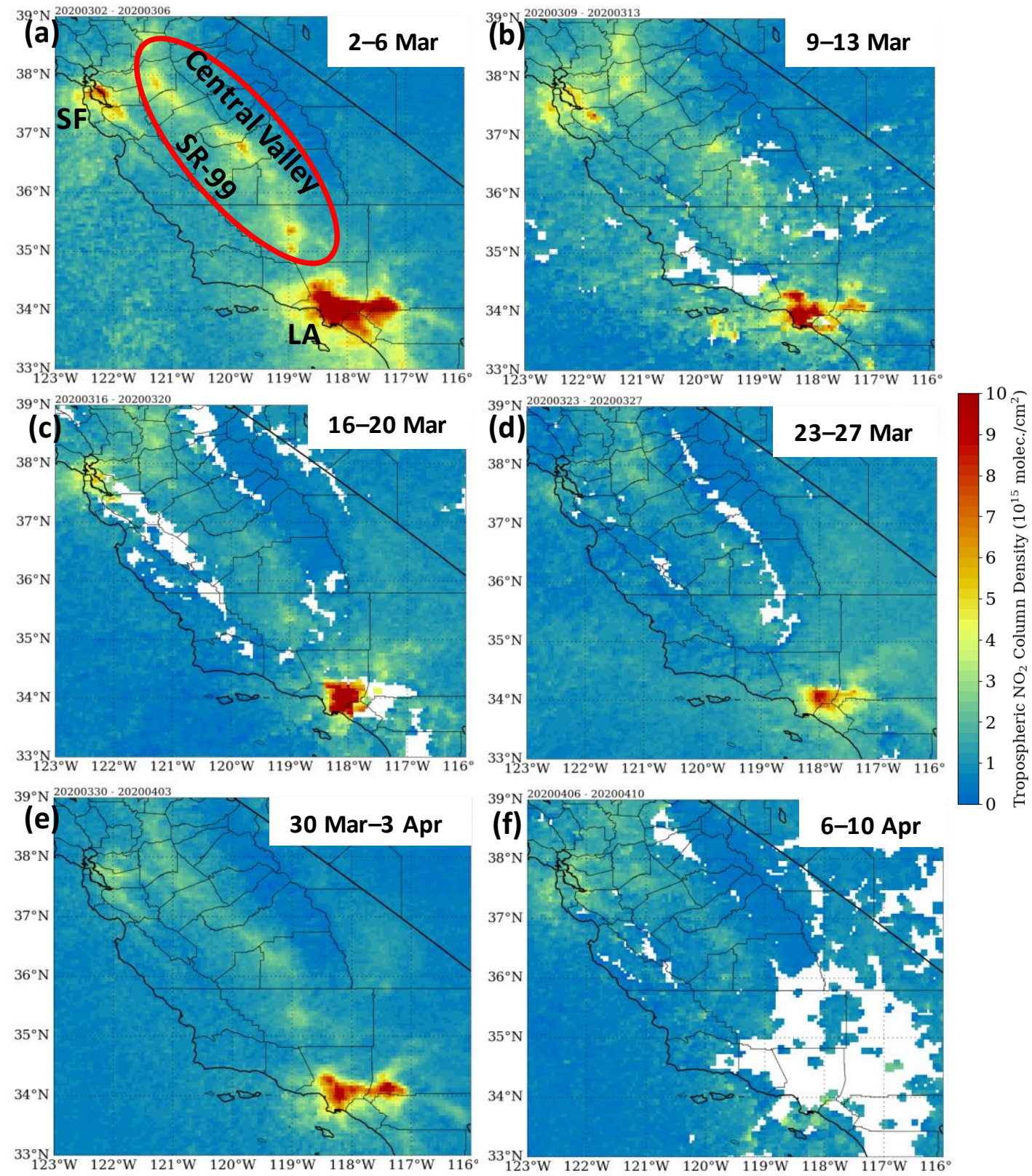

Fig. 3. (a) Gridded $0.05 \times 0.05^{\circ}$ tropospheric $\mathrm{NO}_{2}$ map from TROPOMI OFFL L2 retrievals during $2^{\text {nd }}-6^{\text {th }}$ March 2020 (preCOVID-19 containment period) over California. (b-f) Same as (a), except valid for (b) $9^{\text {th }}-13^{\text {th }}$ March during initial, less strict COVID-19 containment measures, (c) $16^{\text {th }}-20^{\text {th }}$ March when "shelter in place" orders were announced, and full period of "shelter in place" orders during (d) $23^{\text {rd }}-27^{\text {th }}$ March, (e) $30^{\text {th }}$ March- $3^{\text {rd }}$ April, and (f) $6^{\text {th }}-10^{\text {th }}$ April. 
during the previous week due to the considerable washout effect by precipitation. For the final weekday period of March $\left(23^{\text {rd }}-27^{\text {th }}\right.$ March $)$ and into early April (30 ${ }^{\text {th }}$ March$3^{\text {rd }}$ April), we expect minimal impacts from precipitation as the region remained mostly dry. The spatial patterns of tropospheric $\mathrm{NO}_{2}$ during these weekday periods are similar with noticeable $\mathrm{NO}_{2}$ reductions of about $23 \%$ and $43 \%$ relative to the previous week over Los Angeles and San Francisco, respectively (Figs. 3(d) and 3(e)), which coincided with an additional VMT reduction of around $10 \%$ in these cities. A $15 \%$ reduction in $\mathrm{NO}_{2}$ also occurred over Bakersfield during this 2-week period while $\mathrm{NO}_{2}$ was mostly unchanged in Fresno likely due to the enhanced precipitation during the previous week $\left(16^{\text {th }}-20^{\text {th }}\right.$ March). The second week of April (Fig. 3(f)) was characterized by a strong baroclinic system and large precipitation amounts across the region, in addition to persistent cloud cover over southern California that limited the number of valid TROPOMI retrievals.

To better assess the impacts of the COVID-19 containment measures and reduced traffic activity on air pollutant levels in California, we compare the tropospheric $\mathrm{NO}_{2}$ columns observed by TROPOMI during the Phase 2 COVID-19 measures to the same period in 2019. We exclude the second week of April $\left(6^{\text {th }}-10^{\text {th }}\right.$ April) from the analysis when the strong baroclinic system impacted the region. The multi-week gridded TROPOMI maps reveal generally lower tropospheric $\mathrm{NO}_{2}$ columns in 2020 (Fig. 4(a)) compared to 2019 (Fig. 4(b)) over the urban areas of California, especially Los Angeles and around San Francisco. The difference map between 2020 and 2019 shows large $\mathrm{NO}_{2}$ reductions of up to $6.0 \times$ $10^{15}$ molecules $\mathrm{cm}^{-2}$ in Los Angeles along with smaller areas of reductions exceeding 1.2 molecules $\mathrm{cm}^{-2}$ over Fresno and around San Francisco (Fig. 4(c)). Although not a focus area in this study, San Jose also experienced large decreases in $\mathrm{NO}_{2}$ exceeding $3.0 \times 10^{15}$ molecules $\mathrm{cm}^{-2}$. Table 1 summarizes the results of the TROPOMI and VMT analysis in the four selected cities during 2019 and $2020 . \mathrm{NO}_{2}$ amounts represent the average of tropospheric $\mathrm{NO}_{2}$ columns from TROPOMI pixels that fall within a $15 \mathrm{~km}$ radius from the CARB stations located near each city center. Los Angeles, Fresno, and Bakersfield experienced reductions in tropospheric $\mathrm{NO}_{2}$ columns of approximately $40 \%, 38 \%$, and $20 \%$, respectively, which were within about $10 \%$ of the decrease in total VMT. Since Los Angeles is the largest city with the most traffic activity in California, it is not surprising that the largest $\mathrm{NO}_{2}$ reductions occurred in this area. A more surprising result is the $38 \%$ reduction in $\mathrm{NO}_{2}$ relative to 2019 over the less populated city of Fresno, which can be attributed to the largest decrease in total VMT of nearly $50 \%$ partly caused by significantly fewer on-road trucks. Truck activity played an even larger role in the $\mathrm{NO}_{2}$ reductions over Bakersfield where decreases in truck VMT (54\%) from 2019 to 2020 were much larger than the decreases in total VMT (19\%). For San Francisco, the percentage decrease in VMT was much larger than $\mathrm{NO}_{2}$, which can be attributed to less favorable weather conditions for pollution in 2019 compared to 2020. Therefore, the $\mathrm{NO}_{2}$ reduction of $19 \%$ in San Francisco represents the minimum impact from the COVID-19 containment measures.


Fig. 4. Similar TROPOMI tropospheric $\mathrm{NO}_{2}$ maps as in Fig. 3, except for multi-week periods representing the Phase 2 containment period in 2020 compared to analogous period in 2019. Maps are valid for (a) $16^{\text {th }}$ March- $3^{\text {rd }}$ April in 2020 and (b) $18^{\text {th }}$ March $-5^{\text {th }}$ April in 2019. (c) Differences between tropospheric $\mathrm{NO}_{2}$ columns in 2020 and 2019.

We also examine OMI data to understand how different satellite instruments can influence the analysis of the COVID-19 impacts on $\mathrm{NO}_{2}$. The multi-week gridded OMI maps show a noticeable reduction of tropospheric $\mathrm{NO}_{2}$ over Los Angeles in 2020 (Fig. 5(a)) compared to 2019 (Fig. 5(b)) where levels decrease approximately $30 \%$ from about $7.5 \times$ $10^{15}$ molecules $\mathrm{cm}^{-2}$ to $5.2 \times 10^{15}$ molecules $\mathrm{cm}^{-2}$ (Table 1 ). This reduction is comparable to the $40 \%$ reduction observed 


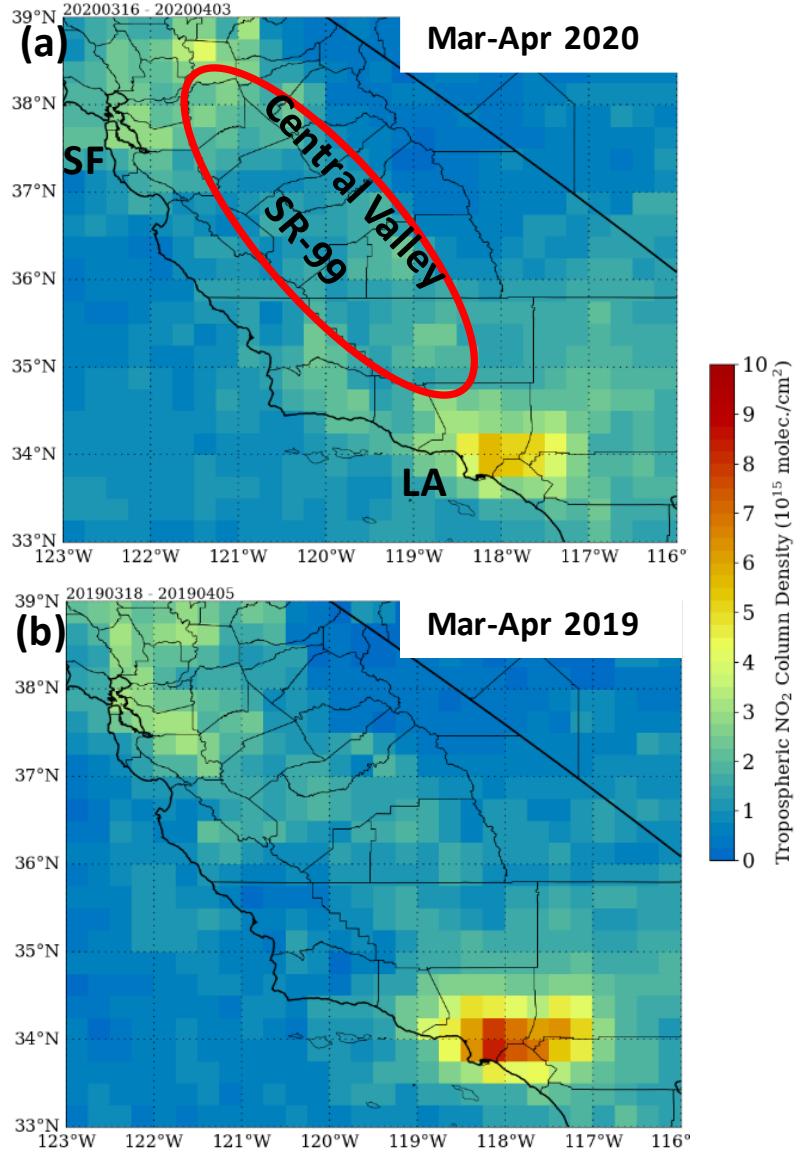

Fig. 5. OMI Level-3 daily global gridded $\left(0.25^{\circ} \times 0.25^{\circ}\right)$ tropospheric $\mathrm{NO}_{2}$ product averaged over 5-week periods representative of the Phase 2 containment period in (a) 2020 and (b) 2019.

by TROPOMI. However, OMI shows drastically different results over the other cities where $\mathrm{NO}_{2}$ levels reduce by only 4\% around San Francisco in 2020 compared to 2019 and actually increase in Fresno and Bakersfield. The OMI NO values over the cities were calculated similar to TROPOMI, except using a $35 \mathrm{~km}$ radius from the CARB stations to account for the coarser resolution of $0.25^{\circ}$ from the OMI data product. It is likely that the improved resolution and instrument sensitivity of TROPOMI is able to better measure $\mathrm{NO}_{2}$ pollution associated with the finer scale emissions from the smaller cities.

\section{Ground-based Air Quality Measurements}

To verify the capabilities of the space-based observations of $\mathrm{NO}_{2}$ and understand the impacts of the COVID-19 containment measures on air pollution at the surface, we utilize ambient $\mathrm{NO}_{2}$ and $\mathrm{PM}_{2.5}$ measurements from CARB ground-based stations near each city center. The instrumentation site located in the city of Los Angeles shows dominantly lower daily averaged $\mathrm{NO}_{2}$ (Fig. 6(a)) and $\mathrm{PM}_{2.5}$ (Fig. 6(b)) concentrations in March-April 2020 compared to 2019 after the initiation of Phase 1 containment measures. A similar trend in $\mathrm{NO}_{2}$ and $\mathrm{PM}_{2.5}$ concentrations are observed in San Francisco (Figs. 6(c) and 6(d)), albeit smaller differences compared to
Los Angeles. However, as previously discussed during the analysis of weekday TROPOMI maps, the meteorological conditions are one of the leading factors for the strong daily variability of pollutant concentrations throughout the time series. When calculating the average $\mathrm{NO}_{2}$ and $\mathrm{PM}_{2.5}$ concentrations for the same 19-day periods in $2019\left(18^{\text {th }}\right.$ March-5 $5^{\text {th }}$ April) and 2020 (16 $6^{\text {th }}$ March- $3^{\text {rd }}$ April), a significant decrease in pollutants are apparent in each city including Fresno and Bakersfield (Table 2), which is in general agreement with the TROPOMI NO 2 observations. In particular, relative differences in ambient $\mathrm{NO}_{2}$ from the ground-based measurements between 2020 and 2019 are within $\pm 6 \%$ of the relative differences in tropospheric $\mathrm{NO}_{2}$ columns from TROPOMI over Los Angeles, Fresno, and Bakersfield. This close agreement indicates that the TROPOMI observations provide a more accurate understanding of the impacts of the COVID-19 containment measures compared to OMI. Our OMI analysis shows a good comparison to the CARB station in Los Angeles, but large discrepancies occur over the other smaller cities, which suggests that OMI is underestimating $\mathrm{NO}_{2}$ related to fine-scale emission sources due to its coarse spatial resolution (Valin et al., 2011). For San Francisco, the larger disagreement between CARB and TROPOMI NO 2 data could be related to a number of factors, including the complex land-sea boundaries in the area, proximity of CARB stations to emission sources, and the limited daytime TROPOMI overpasses. When considering the $43 \%$ decrease in VMT along with the more favorable weather conditions for air pollution in 2020 than in 2019 over San Francisco, the $\mathrm{NO}_{2}$ reductions from CARB ( 30\%) are likely providing the most accurate impacts of the containment measures. Altogether, the TROPOMI and CARB $\mathrm{NO}_{2}$ data provide strong evidence that the containment measures in California promoted $\mathrm{NO}_{2}$ reductions of around $35 \%$ in Los Angeles and Fresno and 25\% in San Francisco and Bakersfield relative to 2019 .

Although the sources and chemistry of atmospheric $\mathrm{PM}_{2.5}$ are much more complex than $\mathrm{NO}_{2}$, the close comparison between the reductions in $\mathrm{NO}_{2}$ and $\mathrm{PM}_{2.5}$ from CARB suggest that the sharp decrease in anthropogenic $\mathrm{NO}_{\mathrm{x}}$ emissions due to the containment measures are contributing to the $\mathrm{PM}_{2.5}$ reductions. Similar to the $\mathrm{NO}_{2}$ analysis, the largest decrease in $\mathrm{PM}_{2.5}$ occurs in Los Angeles where concentrations drop about $36 \%$ from $10.2 \mu \mathrm{g} \mathrm{m}^{-3}$ in 2019 to $6.5 \mu \mathrm{g} \mathrm{m}^{-3}$ in 2020 while Bakersfield experiences the smallest decrease of $25 \%$. These ground-based measurements suggest that the COVID-19 containment measures led to less pollutants and improved air quality conditions at the surface, which can have beneficial effects on human health.

\section{SUMMARY AND CONCLUSIONS}

This study utilized air quality data from satellite and ground-based measurements along with meteorological and traffic datasets to evaluate the impact of the COVID-19 containment measures on air pollution in California during March-April 2020. When comparing March-April 2020 to the same period in 2019, we noted important differences in wind, temperature, and precipitation that could strongly 

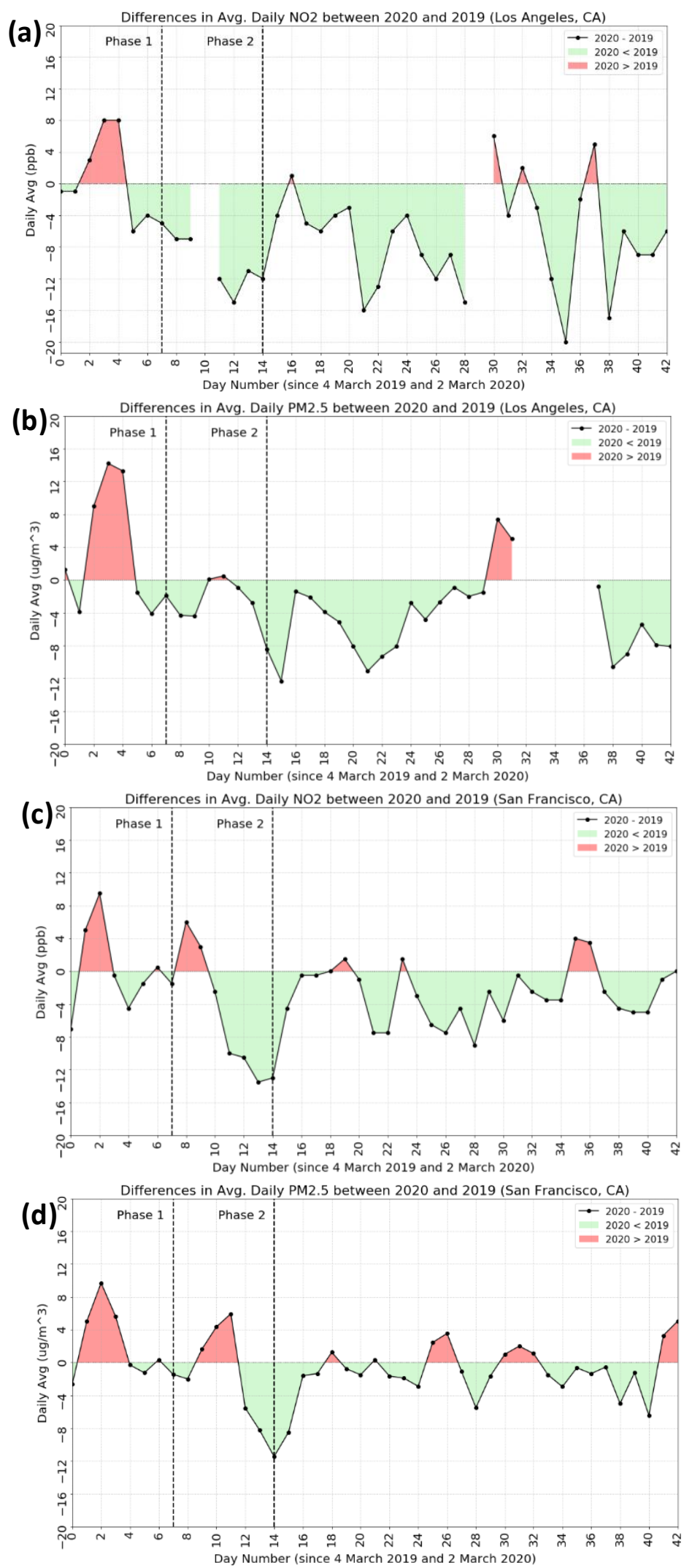

Fig. 6. Differences in daily averaged (a) $\mathrm{NO}_{2}$ and (b) $\mathrm{PM}_{2.5}$ measurements between 2020 and 2019 from the CARB groundbased station in Los Angeles with time series representing pre- and post-initiation of COVID-19 containment measures in 2020. The 42-day time series extends from $2^{\text {nd }}$ March-13 $3^{\text {th }}$ April in 2020 and $4^{\text {th }}$ March-15 ${ }^{\text {th }}$ April in 2019. (c, d) Same as $(\mathrm{a}, \mathrm{b})$, except for CARB stations in San Francisco. Dashed vertical lines represent the start dates of the Phase 1 and 2 containment measures in California. 
Table 2. Average of daily $\mathrm{NO}_{2}$ and $\mathrm{PM}_{2.5}$ measurements from CARB stations located near each city center for period in 2020 during Phase 2 containment measures ( $16^{\text {th }}$ March $-3^{\text {rd }}$ April) and analogous period in 2019 (18 ${ }^{\text {th }}$ March- $5^{\text {th }}$ April). Relative differences in percent between 2020 and 2019 values are shown in bottom row. Units for $\mathrm{NO}_{2}$ and $\mathrm{PM}_{2.5}$ are $\mathrm{ppb}$ and $\mu \mathrm{g} \mathrm{m}^{-3}$, respectively.

\begin{tabular}{|c|c|c|c|c|c|c|c|c|}
\hline \multirow{2}{*}{ Year } & \multicolumn{2}{|c|}{ Los Angeles } & \multicolumn{2}{|c|}{ San Francisco } & \multicolumn{2}{|c|}{ Fresno } & \multicolumn{2}{|c|}{ Bakersfiled } \\
\hline & $\mathrm{NO}_{2}$ & $\mathrm{PM}_{2.5}$ & $\mathrm{NO}_{2}$ & $\mathrm{PM}_{2.5}$ & $\mathrm{NO}_{2}$ & $\mathrm{PM}_{2.5}$ & $\mathrm{NO}_{2}$ & $\mathrm{PM}_{2.5}$ \\
\hline 2019 & 16.2 & 10.2 & 12.8 & 5.4 & 7.3 & 6.4 & 10.0 & 7.2 \\
\hline 2020 & 10.1 & 6.5 & 8.9 & 3.9 & 4.9 & 4.2 & 7.4 & 5.4 \\
\hline 2020-2019 & 37.7 & 36.3 & 30.5 & 27.8 & 32.9 & 34.4 & 26.0 & 25.0 \\
\hline
\end{tabular}

influence air pollutants throughout California. We found that these meteorological factors provided a more favorable environment for enhanced pollutant concentrations in 2020 compared to 2019 over San Francisco. Conversely, periods of large precipitation amounts in 2020 likely contributed to the pollutant reductions over Los Angeles, Bakersfield, and Fresno. Although weekday trends in tropospheric $\mathrm{NO}_{2}$ columns from TROPOMI showed strong $\mathrm{NO}_{2}$ reductions throughout the urban areas of California after implementation of the containment measures, natural weather variability played a key role in governing the pollutant reductions.

To conduct a more detailed quantitative analysis of the air pollution impacts due to the COVID-19 containment measures, we assessed tropospheric $\mathrm{NO}_{2}$ columns from TROPOMI during similar 19-day periods in March-April 2019 and 2020 when conditions were drier across much of the region. We also focused the analysis during the statewide "shelter in place" order when the largest reductions in VMT were observed. Overall, TROPOMI observations revealed strong reductions in tropospheric $\mathrm{NO}_{2}$ of $40 \%$ in Los Angeles, 38\% in Fresno, and about $20 \%$ in Bakersfield and San Francisco relative to 2019 . The reductions were within about $10 \%$ of the decrease in total VMT from 2019 to 2020, except over San Francisco, which indicated that the decrease in trafficrelated $\mathrm{NO}_{\mathrm{x}}$ emissions due to the COVID-19 lockdown were an important driver of the $\mathrm{NO}_{2}$ reduction. Furthermore, we found that decreases in on-road trucks during the lockdown significantly contributed to $\mathrm{NO}_{2}$ reductions over Bakersfield and Fresno. The larger discrepancies between the reductions in VMT and $\mathrm{NO}_{2}$ columns over San Francisco were likely related to the more favorable environment for pollution in 2020 compared to 2019. Our analysis using OMI data showed similar $\mathrm{NO}_{2}$ reductions to TROPOMI over Los Angeles during the containment period, but drastically different results over the other cities where little to no reductions were observed between 2019 and 2020. The generally close agreement between ambient $\mathrm{NO}_{2}$ from ground-based stations and tropospheric $\mathrm{NO}_{2}$ from TROPOMI indicated that the TROPOMI observations provided a more accurate assessment of the impacts from the COVID-19 containment measures compared to OMI. This highlights that the improved resolution and instrument sensitivity of TROPOMI can better characterize $\mathrm{NO}_{2}$ pollution associated with fine-scale emissions from smaller cities. Altogether, the TROPOMI and ground-based $\mathrm{NO}_{2}$ data provide strong evidence that the containment measures in California promoted $\mathrm{NO}_{2}$ reductions of around $35 \%$ in Los Angeles and Fresno and 25\% in San Francisco and Bakersfield relative to 2019, which ultimately led to decreases in $\mathrm{PM}_{2.5}$ and improved air quality conditions at the surface.

\section{ACKNOWLEDGMENTS}

This research was directly supported by Dr. Tsengdar Lee of the NASA Science Mission Directorate's Earth Science Division for the SPoRT program at the NASA Marshall Space Flight Center.

\section{REFERENCES}

Benjamin, S.G., Weygandt, S.S., Brown, J.M., Hu, M., Alexander, C., Smirnova, T.G., Olson, J.B., James, E., Dowell, D.C., Grell, G.A., Lin, H., Peckham, S.E., Smith, T.L., Moninger, W.R., Kenyon, J. and Manikin, G.S. (2016). A North American hourly assimilation and model forecast cycle: The Rapid Refresh. Mon. Weather Rev. 144: 1669-1694. https://doi.org/10.1175/MWRD-15-0242.1

Chen, C. (2003). Freeway performance measurement system (PeMS). Research Report UCB-ITS-PRR-200322. University of California, Berkley, CA.

Daly C., Halbleib M., Smith J.I., Gibson W.P., Doggett M.K., Taylor G.H., Curtis J. and Pasteris P.P. (2008). Physiographically sensitive mapping of climatological temperature and precipitation across the conterminous United States. Int. J. Climatol. 28: 2031-2064. https://doi.org/10.1002/joc.1688

Grundstrőm, M., Hak, C., Chen, D., Hallquist, M. and Pleije, H. (2015). Variation and co-variation of $\mathrm{PM}_{10}$, particle number concentrations, $\mathrm{NO}_{\mathrm{x}}$ and $\mathrm{NO}_{2}$ in the urban airRelationships with wind speed, vertical temperature gradient and weather type. Atmos. Environ. 120: 317327. https://doi.org/10.1016/j.atmosenv.2015.08.057

Ho, W.C., Hartley, W.R., Myers, L., Lin, M.H., Lin, Y.S., Lien, C.H. and Lin, R.S. (2007). Air pollution, weather, and associated risk factors related to asthma prevalence and attack rate. Environ. Res. 104: 402-409. https://doi.org/ 10.1016/j.envres.2007.01.007

Hudman, R.C., Russell, A.R., Valin, L.C. and Cohen, R.C. (2010). Interannual variability in soil nitric oxide emissions over the United States as viewed from space. Atmos. Chem. Phys. 10: 9943-9952. doi:10.5194/acp-109943-2010

Karagulian, F, Belis, C.A., Dora, C.F.C., Pruss-Ustün, A. M., Bonjour, S., Adair-Rohani, H. and Amann, M. (2015). Contributions to cities' ambient particulate matter (PM): A systematic review of local source contributions at 
global level. Atmos. Environ. 120: 475-483. https://doi.org/10.1016/j.atmosenv.2015.08.087

Kim, K.H., Kabir, E. and Kabir, S. (2015). A review on the human health impact of airborne particulate matter. Environ. Int. 74: 136-143. https://doi.org/10.1016/j.envin t.2014.10.005

Kim, S., Hong, K.H., Jun, H., Park, Y.J., Park, M. and Sunwoo, Y. (2014). Effect of precipitation on air pollutant concentration in Seoul, Korea. Asian J. Atmos. Environ. 8: 202-2011. https://doi.org/10.5572/ajae.2014.8.4.202

Klimont, Z., Kupiainen, K., Heyes, C., Purohit, P., Cofala, J., Rafaj, P., Borken-Kleefeld, J. and Schöpp, W. (2017). Global anthropogenic emissions of particulate matter including black carbon. Atmos. Chem. Phys. 17: 86818723. https://doi.org/10.5194/acp-17- 8681-2017

Lambert, J.C., Keppens, A., Hubert, D., Langerock, B., Eichmann, K.U., Kleipool, Q., Sneep, M., Verhoelst, T., Wagner, T., Weber, M., Ahn, C., Argyrouli, A., Balis, D., Chan, K.L., Compernolle, S., De Smedt, I., Eskes, H., Fjæraa, A.M., Garane, K., ... Wang, P. (2019). Quarterly Validation Report of the Copernicus Sentinel-5 Precursor Operational Data Products - \#02: July 2018-February 2019. S5P Mission Performance Centre. http://www.trop pomi.eu/sites/default/files/files/publicS5P-MPC-IASB-R OCVR-02.0.2-20190411_FINAL.pdf

Lamsal, L.N., Krotkov, N.A., Celarier, E.A., Swartz, W.H., Pickering, K.E., Bucsela, E.J., Gleason, J.F., Martin, R.V., Philip, S., Irie, H., Cede, A., Herman, J., Weinheimer, A., Szykman, J.J. and Knepp, T.N. (2014). Evaluation of OMI operational standard $\mathrm{NO}_{2}$ column retrievals using in situ and surface-based $\mathrm{NO}_{2}$ observations. Atmos. Chem. Phys. 14: 11587-11609. https://doi.org/10.5194/acp-1411587-2014

Lamsal, L.N., Martin, R.V., Padmanabhan, A., van Donkelaar, A., Zhang, Q., Sioris, C.E., Chance, K., Kurosu, T.P. and Newchurch, M.J. (2011). Application of satellite observations for timely updates to global anthropogenic $\mathrm{NO}_{\mathrm{x}}$ emissions inventories. Geophys. Res. Lett. 38: L05810. https://doi.org/10.1029/2010GL046476

Lee, H., Park, S.J., Lee, G.R., Kim, J.E., Lee, J.H., Jung, Y. and Nam, E.W. (2020). The relationship between trends in COVID-19 prevalence and traffic levels in South Korea. Int. J. Infect. Dis. 96: 399-407. https://doi.org/10. 1016/j.ijid.2020.05.031

Lurmann, F., Avol, E. and Gilliland, F. (2015). Emissions reduction policies and recent trends in Southern California's ambient air quality. J Air Waste Manage. Assoc. 65: 324-335. https://doi.org/10.1080/10962247.2 014.991856

McDonald, B.C., Dallmann, T.R., Martin, E.W. and Harley, R.A. (2012). Long-term trends in nitrogen oxide emissions from motor vehicles at national, state, and air basin scales. J. Geophys. Res. 117: D00V18. https://doi.org/10.1029/ 2012JD018304

Parrish, D.D., Singh, H.B., Molina, L. and Madronich, S. (2011). Air quality progress in North American megacities: A review. Atmos. Environ. 45: 7015-7025.

Seinfeld, J.H. and Pandis, S.N (2006). Atmospheric chemistry and physics: From air pollution to climate change. John Wiley and Sons.

Strak, M., Janssen, N., Beelen, R., Schmitz, O., Vaartjes, I., Karssenberg, D., van den Brink, C., Bots, M. L., Dijst, M., Brunekreef, B. and Hoek., G. (2017). Long-term exposure to particulate matter, $\mathrm{NO}_{2}$ and the oxidative potential of particulates and diabetes prevalence in a large national health survey. Environ. Int. 108: 228-236. https://doi.org/10.1016/j.envint.2017.08.017

Torres, O., Tanskanen, A., Veihelmann, B., Ahn, C., Braak, R., Bhartia, P.K., Veefkind, P. and Levelt, P. (2007). Aerosols and surface UV products from Ozone Monitoring Instrument observations: An overview. $J$. Geophys. Res. 112: D24S47. https://doi.org/10.1029/200 7JD008809

Valin, L.C., Russell, A.R., Hudman, R.C. and Cohen, R.C. (2011). Effects of model resolution on the interpretation of satellite $\mathrm{NO}_{2}$ observations. Atmos. Chem. Phys. 11: 11647-11655. https://doi.org/10.5194/acp-11-11647-2011

Veefkind, J.P., Aben, I., McMullan, K., Förster, H., de Vries, J., Otter, G., Claas, J., Eskes, H.J., de Haan, J.F., Kleipool, Q., van Weele, M., Hasekamp, O., Hoogeveen, R., Landgraf, J., Snel, R., Tol, P., Ingmann, P., Voors, R., Kruizinga, B., ... Levelt, P.F. (2012). TROPOMI on the ESA Sentinel-5 Precursor: A GMES mission for global observations of the atmospheric composition for climate, air quality and ozone layer applications. Remote Sens. Environ. 120: 70-83. https://doi.org/10.1016/j.rse.2011.0 9.027

Yan, F., Winijkul, E., Jung, S., Bond, T.C. and Streets, D. G. (2011). Global emission projections of particulate matter (PM): I. Exhaust emissions from on-road vehicles. Atmos. Environ. 45: 4830-4844. https://doi.org/10.1016/ j.atmosenv.2011.06.018

Zhou, Y., Brunner, D., Hueglin, C., Henne, S. and Staehelin, J. (2012). Changes in OMI tropospheric $\mathrm{NO}_{2}$ columns over Europe from 2004 to 2009 and the influence of meteorological variability. Atmos. Environ. 46: 482-495. https://doi.org/10.1016/j.atmosenv.2011.09.024

Received for review, May 15, 2020 Revised, August 3, 2020 Accepted, August 9, 2020 